\title{
Refik Halit Karay ile sürgün kadın kahramanlarının ortak özellikleri ${ }^{1}$
}

\section{Necla DAĞ $\breve{G}^{2}$}

APA: Dağ, N. (2019). Refik Halit Karay ile sürgün kadın kahramanlarının ortak özellikleri. RumeliDE Dil ve Edebiyat Araşturmaları Dergisi, (Ö5), 187-197. DOI: 10.29000/rumelide.606115.

\section{$\ddot{\mathbf{O} z}$}

Sürgünlük kavramı siyasi, sosyal, ekonomik sebeplerden kaynaklı cezalandırılma, belli bir süre veya daimi olarak yerinden edilme, başka bir yere gönderilme durumlarını ifade eder. Çoğunlukla göç olgusuyla birlikte ele alınan bu kavram, irade dışında gerçekleşmesi yönüyle göç ile bazı farklılıkları içermektedir. Bu çalışmada sürgün kavramı hayatının iki döneminde sürgün cezasına çarptırılan Türk edebiyatının önemli isimlerinden Refik Halit Karay'ın yaşamı ve eserleri üzerinden değerlendirilecektir. Sürgüne gönderildiği beş yıl boyunca Anadolu'da ve Anadolu dışındaki hayatında gözlem yeteneğini kullanarak sürükleyici roman kurguları oluşturan yazarın ulaşım imkânlarının sınırlı olduğu dönemlerde yaptığı yolculukların eserlerine yansımaları üzerinde durulacaktır. Refik Halit, bu sürgün yolculukları sırasında insanları gözlemleyerek eserleri için kahramanlar biriktirir. Kendi yaşamında bazı olayları kurguya dâhil ederek olayları gerçekçi bir zemine oturtmaya çalışır. Türk edebiyatında genellikle siyasi, sosyal veya başka nedenlerden dolayı sürgün edilen erkek kahramanların hayatını ele alan eserler mevcuttur. Refik Halit; Yezidin Kızı, Çete ve Nilgün romanlarında diğer eserlerin aksine sürgün erkekleri değil; kadın kahramanları ele alarak farklı bir yaklaşım sergiler. Farklı kültürlerin temsilcileri olan roman kahramanları Zeli, Nina ve Nilgün çeşitli nedenlerle sürgüne mahkûm olmuşlardır. Yazar, sürgünün kadın psikolojisinde açtığı yaraları bu kahramanların kişilikleri üzerinden derinlemesine irdeler. Genellikle herkesin dikkatini çekecek güzellikte ve güçlü yapıda, çok iyi silah kullanan, birkaç yabancı dil bilen, iyi eğitim almış bu kadınların hemen hepsinin uzun yolculuklara çıktıkları ve çeşitli maceralar yaşadıkları görülür. Belli bir amaç ile yola çıkan bu kadınların casus rolü üstlenmeleri, tımarhanede kalmış olmaları ya da ruhsal hastalıklarla ile ilgili tedavi görmüş olmaları diğer ortak özellikleridir. Bu çalışmada yazarın Yezidin Kızı, Çete ve Nilgün romanlarındaki kadın kahramanların yaşadıkları sürgün hayatı ve bu kadınların ortak özellikleri üzerinde durulacaktır.

Anahtar kelimeler: Sürgün, kadın kahramanlar, Nilgün, Yezidin kızı, çete.

\section{Common characteristics of Refik Halit Karay and female heroes in exile}

\begin{abstract}
The concept of deportation refers to the situation of being punished for political, social, economic reasons, being displaced for a certain period of time or permanently, being sent to another place. This concept, which is mostly dealt with in conjunction with the phenomenon of migration, includes some differences with migration in the way that it takes place outside the will. In this study, the concept of exile will be evaluated through the life and works of Refik Halit Karay, one of the important figures of Turkish literature who was sentenced to exile during the two periods of his life. During the
\end{abstract}

Çalışma, 2. Uluslararası Rumeli (Dil, Edebiyat, Çeviri) Sempozyumunda sözlü bildiri olarak sunulmuştur. Çalışmanın "Refik Halit Karay’ı İdeal İnsan Örnekleri: Kadınlar” olan başlığı, "Refik Halit Karay ile Sürgün Kadın Kahramanlarının Ortak Özellikleri” seklinde değiștirilmistir.

2 Öğr. Gör. Dr., Aksaray Üniversitesi, Türk Dili Bölümü (Aksaray, Türkiye), necladago2@gmail.com, ORCID ID: oooo0002-7961-2960 [Makale kaylt tarihi: 08.06.2019-kabul tarihi: 18.08.2019; DOI: 10.29000/rumelide.606115] 


\begin{abstract}
five years of his exile in Anatolia and in his life outside Anatolia, he will focus on his reflections on the works of the author, who created immersive novel fiction using his ability to observe, and his journeys during periods when transportation opportunities were limited. Refik Halit accumulates heroes for his works by observing humans during these exile journeys. He tries to put some events in his own life on a realistic basis by incorporating them into his fiction. Turkish literature often features works that address the lives of exiled male protagonists for political, social or other reasons. Refik Halit; Daughter of Yazid, not exiled men unlike other works in the Gang and Nilgün novels; takes a different approach by addressing female protagonists. Heroes Zeli, Nina and Nilgün, who are representatives of different cultures, have been sentenced to exile for various reasons. The author delves deeply into the wounds inflicted by exile in the psychology of women through the personalities of these heroes. It is often seen that almost all of these well-educated women, who use very good weapons and speak a few foreign languages, have long journeys and have various adventures, with the beauty and strength to attract everyone's attention. The other common characteristics of these women, who set out with a certain purpose, to take on the role of spies, to be stuck in an asylum or to be treated for mental illness are. In this study, Daughter of Yazid, Gang and Nilgün novels, the lives of the female protagonists of exile and the common characteristics of these women will be discussed.
\end{abstract}

Keywords: Exile, women's characters, Nilgün, Yezid's daughter, gang.

\title{
Giriş
}

\section{Refik Halit'in sürgün hayatının romanlarına yansımaları}

Sürgünlük, siyasal, sosyal ve bireysel bir kavram olarak ele alınabilir. Bireyin bir yerden başka bir yere zorunlu olarak belli bir dönem için veya sürekli kalacak şekilde gönderilmesini ifade eden sürgün kavramının yerine başka ifadeler de kullanılmaktadır. Nedim Gürsel (1996: 29) sürgün sözcüğünün kültürümüzde pek yer edinmediğini, bu kelimenin yerine "gurbet" kelimesinin tercih edildiğini belirtir. Gurbet kelimesinin çağrıştırdığı "garip olma”, "sürekli bir özlem ve yalnızlık hali” içinde olma hali de sürgün durumu ile birlikte kullanılmaktadır. Gürsel'in bu tanımına göre gurbet veya sürgünlük, "yalnızca köyünden, sevdiklerinden ve yaşadığı topraktan ayrılmak değildir, uzakta olmanın "ölümden beter” ayrılığın yol açtığı bir tinsel durumdur.” Oya Baydar (1996: 41) ise siyasal sürgünlüğü "yurdundan, toprağından, ikliminden ayrılıp yabancı diyarlarda yaşamak zorunda kalmanın en ağır biçimi” şeklinde tanımlar. Yersiz, vatansız ve kimsesiz kalma durumlarını barındıran bu kavramı Feridun Andaç (1996, 11), "karşı konulan, savaşılan koşullarda yenik düşme sonrasında kaçınılıp sığınılacak bir yer/yurt arayışı” olarak tanımlar. Andaç’ın bu tanımından yola çıarak değerlendirme yapılacak olursa karşı konulan koşullara yenik düşen bireyin sonraki süreçte gönüllü ya da zoraki olarak bu yola girmesinin kaçınılmaz olduğu söylenebilir. Belirsizlik ve korkuyla başlayan bu süreç, ani bir karar ile yola çıkışı ve sonraki zaman diliminde yalnızlık, özlem ve herhangi bir yere ait olamama durumlarını beraberinde getirir. Ancak sürgün birey, içinde bulunduğu koşulların ağırlı̆̆ı nedeniyle ilk önce bu şartlardan kurtulmayı hedeflediğinden gideceği yerin kendisine sürekli yalnızlığı, geçmiş yaşamına özlemi ve yurtsuzluğu sunacağını düşünemez.

Türk siyasi ve edebiyatının önemli kalemleri dönemlerinin koşullarına göre sürgün hayatı yaşamak zorunda kalmışlardır. Sürgün cezası alan ünlü isimlerden bazıları; "Ahmet Mithat Efendi, Namık Kemâl, Ali Suavi, Refik Halit, Aziz Nesin, Bereketzâde İsmail Hakkı, Menâpirzâde Nuri, Abdülhalim Memduh gibi isimlerdir (Acehan, 2007:11). Bu isimler eserlerinde sürgün hayatına ait hatıralara sıkça yer verdikleri gibi sürgünü yaşayan kahramanların öykülerini yazmayı da ihmal etmezler. Örneğin; Bekir 
Fahri, Mısır'da Jönler'de, Halit Ziya Uşaklığil, Nesl-i Ahir'de, Yakup Kadri Hüküm Gecesi ve Bir Sürgün romanlarında sürgün hayatını veya sürgün edilme korkusunu işlerler. Bunun gibi pek çok örnek bulunmaktadır; ancak bu eserlerin çoğunda erkek kahramanların sürgün hayatına dikkat çekilmiş, yaşanan sorunlara bu çerçeveden bakılmıştır.

Mitoloji, masal ve modern öykü gibi türlerde kahramanların kendilerini bulmaları yola çıkmayla birlikte başlar. Bu kahramanlar yolculuklarında belli bir arketipsel modeli izleyerek yol alırlar. Kahramanın alıştı̆̆ı, bildiği çevreden ayrılarak türlü maceralara atılacağı ortama girişi ve planlı ya da tesadüfen gelişen durumların kendisine kazandırdıklarıyla bir geri dönüş süreci başlar. Böylece kahraman giriştiği maceradan döndüğünde daha güçlü bir kimlik veya kazanımla geri döner. Genellikle yaşadığı ortam ile bir uyuşmazlık içinde olan ve bunun sonucu olarak yurdunu, konumunu, ailesini ve sahip olduğu diğer şeyleri geride bırakıp bilmediği yabancı yerlere gitme görevini üstlenen erkek kahramanlar karşımıza çıkar. İçsel ve fiziksel yolculuğa çıkan kadın kahramanın yaşadıklarının çok da fazla işlenmediği görülmektedir. Çalışmamızda ise sürgün hayatını uzun süre yaşayan hikâyeci, romancı ve gazeteci olan Refik Halit’in diğer yazarlardan farklı olarak işlediği sürgün kadınların hayatı ele alınmaktadır. Dolayısıyla çalışmada, kadın sorunu meselesinden çok sürgünün kadın psikolojisi üzerindeki etkisi ana çerçeveyi oluşturmaktadır.

Refik Halit, Kirpi takma adıyla siyasi mizah yazılarında İttihat ve Terakki'ye ağır eleştiriler yazması nedeniyle Sinop'a sürülür. 1919'da Damat Ferit hükümeti tarafından Posta Telefon Telgraf Müdürlüğüne getirilir. Daha sonraki süreçte Damat Ferit, aleyhinde bulunduğu öğrenilince memuriyetten azledilir. Refik Halit, Posta Telgraf Umum Müdürlüğü yaptığı dönemde Anadolu'da başlayan Milli Mücadele hareketinin karşısında yer alması ve çeşitli yazılarında bu harekete yönelik eleştirilerde bulunması nedeniyle "Yüzellilikler Listesi"ne dâhil edilir. Minelbab İllelmihrab adlı hatıra kitabında Ali Kemal'in tevkif edildiğini öğrendikten sonra Ali Kemal ile aynı akıbeti yaşamamak için diğer muhalifler gibi kendisinin de İngiliz Sefareti’ne sığındığını, burada gördüğü manzaradan sonra dayanamayacak hale geldiğini belirten Refik Halit'in romanlarını anlamak için bu dönemde yaşadıklarını bilmek gerekir. Refik Halit, (1986: 32) kaçış sürecinde yaşadığı sıkıntıları "Vaziyet dayanılır gibi değildi. Nerede yemek yiyecek, nerede yatacak, bu halk arasında kaç gün, kaç ay beraber yaşayacaktım? Sakin odam, temiz yatağım gözümün önüne geldi; gözlerimin dolup boşanmasına ramak kaldı" şeklinde ifade eder. Yazarın eserlerine yansıyacak olan bu kaçış ve sürgün süreci onun "kendisini kampa sevk edilecek bir harp esiri” gibi görmesine neden olur. Türk tarihinde sıkça anılan Bekirağa Karakoluna daha önce düşmüş olan yazar: "Kaderimde Bekirağa'yı görüp tanıdıktan sonra meğerse Taşkışla ile de teşerrüf etmek varmış!” (2009, 330) diyerek yaşadığı duruma hayıflanır. İçinde bulunduğu şartların ağırlığı nedeniyle bir sarsıntı geçirir ve bunun etkisiyle yakalanmadan yurdu terk etmeye karar verir. Fransız elçiliğinde önemli bir görevde olan arkadaşı vasıtasıyla Fransız elçiliğine başvurarak bir belge alır. Böylece Rodos'tan sonra Beyrut'a gidecek “Piyer Loti” vapuruyla Fransızlardan aldığı bir belge ile Beyrut'a güvenli bir şekilde varmayı başarır. Refik Halit, (2009: 341) bu kaçış ile ilgili duyduğu üzüntüyü "Şaka değil, kim bilir ne kadar zaman için, belki de müebbeden memleketi terk ediyordum. Memleketi, evimi, idarehanemi, varımı, yoğumu, her şeyimi... Ben, birdenbire iki eşya çantasından ibaret kalıvermiştim" sözleriyle belirtir. Ailesi ile İstanbul'dan ayrılan (9 Ekim 1922) Refik Halit, Beyrut'ta Cünye'ye yerleşir ve 1927'ye kadar Cünye'de kalır. Bu yllarda Refik Halit'in maddi durumu iyice kötüleşir. Evinin kirasını ödeyemeyecek duruma gelince ilk eşi Nazıma Hanım'ı ve oğlu Ender'i İstanbul'a gönderir. 1938'de Af Kanunu ile yurda dönene kadar sürgünlüğün verdiği her türlü zorluğu yaşayan yazarın eserlerinde bu yaşamının izlerini bire bir görmek mümkündür. Refik Halit’in ikinci sürgün döneminde yazdığı romanlarda, genç kadın kahramanların siyasi, sosyal veya bireysel koşullar nedeniyle ülkelerinden ayrılmış olmaları yazarın sürgün dönemine ait izleri taşır. Sürgünü 
yaşamış veya dolaylı olarak sürgünden etkilenmiş bireylerin durumu; kimlik bunalımı, köksüzlük, geçmiş yaşantıları etrafında işlenir.

\section{Roman kurguları ve kadın kahramanlar}

Yola çıkış bazen bir bitişi ifade ederken bazen de bir kahramanın yeniden doğuşu anlamına gelir. Göze'ye göre, (2013: 1797). "sıradan kişinin ya da doğuştan kaderinde kahramanlık olan özel kişinin, kahraman olabilmek için gündelik dünyasından koparak bir yolculuğa çıkması gerekmektedir.” Campbell (2000: 47-48) ise kahramanın yol ve yolculuk serüvenini üç aşamaya ayırır: Ayrılma ya da yola çıma, erginlenmenin sınavları ve zaferleri aşaması, dönüş ve toplumla yeniden kaynaşma. Olağan dünyadan alışık olduğu düzeni ve uzun bir zaman diliminde elde ettiği rahatı bırakma pahasına yolculuğu göze alan kahramanın yolu "labirent, mağara, orman, yabancı bir şehir ya da ülke gibi gerçek mekânlara" (Göze, 2013: 1797) veya düşsel mekanlara düssebilir. Refik Halit’in kadın kahramanları daima yoldadır ve bu yol genellikle kahramanları vapur ya da gemilerle yapılan uzun bir deniz yolculuğuna çıarır. Yolculuk halinin kısa bir süreliğine bittiği durumlarda Lübnan dinlenme, durak mekân olarak kullanılır. Kahramanların geçirdiği sınavlara göre gidilen mekân çeşitlenir. Bu mekânlar; bazen bir çöl, bazen bir dağ başı, bazen de farklı kültürlere ev sahipliği yapan ülkeler olur. Bütün yolculukların sonu ise kahramanın daha sakin bir hayat yaşamaya karar vermesiyle son bulur. Kahramanların yaşadıkları serüvenler sonunda kendileri ve toplumla barışı hale geldikleri, maceracı kimliklerini bir kenara bırakarak daha huzurlu bir hayat yaşamaya karar verdikleri görülür.

\subsection{Yezidi prensesi: Zeli Della Yezda}

Refik Halit’in 1939 yılından sonra, roman türündeki eserleri art arda yayınlanır. "Yezidin Kızı (1939), Çete (1941), Nilgün (1960) romanları yazarın 1922'de Beyrut’ta başlayan ikinci sürgün döneminden izler taşırlar. Bu romanlarda Ortadoğu, Suriye ve özellikle Lübnan ile ilgili önemli siyasi, kültürel ve sosyolojik değerlendirmeler dönemsel şartlar üzerinde özellikle durulur. Coğrafi bölgeler, kişiler ve siyasi ilişkiler bakımından önem arz eden bu romanlarda İstanbul'daki siyasi durum ve komşu ülkelerdeki karışıklıklara sık sık değinilir. Yıkılan Osmanlı devletinin kalan izleri kadar kurulan yeni devletin oluşumları, dinamikleri ve değerlerine yönelik söylemler geliştirilir. Refik Halit, sürgündeyken, Yezidin Kızı romanını Akşam gazetesine gönderir. Bu süreçte "Yüz Ellilikler"in Türkiye'de yayın yapmaları yasak olduğundan romanın basımı Türkiye'de yapılamaz. Roman, 1937'de Halep’te basılır.

Yezidin Kızı, Arjantin'den Irak’a kadar uzanan geniş bir coğrafyayı ele alan egzotik bir roman örneğidir. Yezidilerin sorunları, toplum olma istekleri, tarihleri, inançları üzerine kurulu olay örgüsünde asıl kurguyu Zeli ve Hikmet Ali'nin hikâyesi oluşturur. Marsilya'dan kalkan vapura binen Hikmet Ali, Suriye'deki köyüne gidecektir. Hikmet Ali, yolculuk sırasında önüne gelenle konuşup ahbap olan, her şeye alaka gösteren insanlardan değildir. Vapurun güvertesine çıkarak tek başına geçirmek istediği yolculuk için uygun bir köşe bulmaya çalışır. Birkaç tur dolaştıktan sonra güvertede beyazlar içinde uzun boylu, "esmer, kehribar renginde gözleri, ağda rengi gölgeli saçları" olan bir kız görür. Kızın yanında beliren "tıknaz, sakallı, kara bir opereti andıran kalın", yayvan vücutlu adam, Hikmet Ali'nin kıza odaklanmasına neden olur. Genç kız, elinde İspanyolca bir gazete olmasına rağmen yanındaki adamla Kürtçe konuşmaktadır. Hikmet Ali'nin kendisine baktığını görünce toparlanıp sözlerine İspanyolca devam eden kadından şüphelenen Hikmet Ali, gemi komiserinden kadının kimliği ile ilgili bilgi almak ister. Öğrendikleri karşısında şaşkına döner; çünkü merak ettiği bu kadın, Hikmet Ali hakkında gemi komiserinden daha önce bilgi almıştır. Böylece Hikmet Ali istemese de olayların içinde kendisini bulur. Gemi komiseri, Zeli Della Yezda’nın Arjantin’in Mendoza şehrinde 1910 senesinde doğduğunu, çok 
büyük arazilerin sahibi olduğunu, kendisini vapura kadar Arjantin’in Marsilya konsolosunun getirdiğini ve Beyrut'a, oradan da çöldeki harabeleri gezerek Bağdat'a gideceğini belirtir. Ana dili kadar akıcı bir şekilde Fransızca, Arapça ve Kürtçe konuşan Zeli, Suriye hakkında sağlam bilgiye sahip birisinin kendisine eşlik etmesini istemektedir. Arjantin'de doğan Zeli'nin daha önce Asya'ya hiç gelmemiş olmasına rağmen Kürtçe konuşması, Hikmet Ali’nin onun bir casus olduğu düşüncesine kapılmasına yol açar. Bu nedenle komiserden kendisini Zeli Della Yezda'ya Suriye seyahati için takdim etmesini ister. Böylece roman kahramanları Zeli ve Hikmet Ali bu deniz yolculuğunda bir araya gelmiş olurlar. Hikmet Ali Suriye'nin idare şeklinin değiştiğini bu nedenle Suriye'de yenilikler ve ayrılıkların olduğundan bahseder. Bunun üzerine siyasi yapısı kadar gideceği coğrafyanın kültürel, ekonomik, dini tüm yönlerini bilen Zeli’nin orada konuşulan çeşitli dilleri bildiği ortaya çıkar. Diyaloglarda Zeli’nin yalnızca Suriye hakkında değil, Lübnan ve kurulan yeni devletler hakkındaki bilgisinin herkesin dikkatini çekecek şeyler olmadığı üzerinde durulur. Türkiye hakkında neler bildiğini öğrenmek isteyen Hikmet Ali, aldığı cevap karşısında muhatabının sıradan bir yolcu olmadığının farkına varır. Çünkü Zeli, Türkiye'nin illerinden siyasi hayatının temellerine, yeni ırk politikasına kadar birçok konuya hâkimdir.

"Eski vilayetlerinizin küçültülerek artan rakamını mı vereyim? Altmış üç! Cumhuriyet Halk Partisi’nin bayrağındaki altı okun neye işaret ettiklerini mi anlatayım? Cumhuriyetçiyiz, milliyetçiyiz, halkçıyı, laikiz, devletçiyiz, inkılapçıyız... Yoksa Sümerlere, Hititlere dayanan yeni ırk nazariyenizi mi izah edeyim?” (YK, 14)

Hikmet Ali bir casusla karşı karşıya kaldığını düşündüğünden Zeli’nin Türkiye'ye ne gibi bir zarar vermeyi planladığını çözmeye çalışır. Onunla birlikte hareket etmenin ülkesine zarar verip vermeyeceğini çözmeye çalıştıkça uykuları kaçar. Bir yandan da onun kim olduğunun peşine düşmemenin milli bir kayıtsızlı ve ihanet olacağını düşünür. Hikmet Ali ile Zeli vapurdaki yolculuktan bir ay sonra Aynizennube köyünde görüşmek üzere sözleşir. Zeli, yeni yıl kutlaması sırasında Yezidi mezhebine mensup olduğunu, cemaate ismini veren Yezid’in de kızı olduğunu söyler. Assl isminin Zeliha olduğunu ama bunun İspanyollaştırarak Zeli dediğini, yanındaki adamın da onun kölesi Şeyh Şemun olduğunu açıklar. Zeli; Türkiye, Kafkasya Surhdar, Hindistan, Lebkos, Sincar ve Irak’taki Yezidi cemaatinin üyelerini bir çatı altında toplayarak birleştirmeyi ve bir Yezidi devleti kurmayı amaçladığını açıklar. Zeli’nin planının uygulanamayacağını bilen Hikmet Ali, bu esrarengiz kadından ayrı kalmak istemediği için tehlikeli yolculuğunda ona eşlik etmeye devam eder. Yezidilerin yaşadıkları yerlere geziler düzenlerler. Zeli, milleti için kuracağı yurdun güvenli bir bölgede yer alması için ön araştırma yapar. Zeli, kuracağı yurdun ayrıntıları kadar Yezidiliğe ait inançlar, ibadetler, erdemler, tarihi bilgiler üzerinde de durur. Bu süreçte Zeli’nin yaşadığı sürgünler, ailesinin ve soydaşlarının uğradığı muameleye sıkça değinilir.

“O zaman Babıali, Yezidilerin tarafını tutmuş ve 1835'te ordu yollayarak sergerdeyi başımızdan def etmişti. 1892 bizim için kan ve ateş yılıdır... Daha evvel de büyük felaketlere uğramıştık.” (YK, 54)

Geçmişte yaşanan sürgünlere göndermeler yapılarak tasarlanan yeni ülkede vatandaşların gelecekte güvenli bir yaşam sürmelerinin önemi vurgulanır. Sakarya ve Dumlupınar savaşlarına katılmış, Mustafa Kemal ile silah arkadaşlı̆̆ı yapmış, vekillikten sonra her şeyden elini ayağını çekip uzaklaşmak amacıyla yola çıkan Hikmet Ali'nin aksine Zeli yeni bir yurt kurmanın heyecanını yaşamaktadır. Hikmet Ali, tüm ayrıntıların düşünüldüğü bu projeyi önceleri onaylamasa da Zeli'yi tanıdıkça takdir etmeye başlar. Sincar Dağı'nda geçirdikleri zaman içerisinde Zeli ve Hikmet Ali birbirine iyice bağlanır. Bir müddet Zeli, oradaki görevliler ve şatodaki hayat içinde oyalanır; ancak bir zaman sonra ortamdan sıkılmaya başlar. Sadece huzur bulduğu yer Hikmet Ali’nin şatodaki odası olur. Bir masal sultanlığı rolünü andıran vazifesinden sıkılmaya başlar. Servetiyle ve güzelliğiyle her istediği yerde kraliçe gibi yaşayabileceğini düşünür. Irak sınırına kadar süren yolculukta bir gün Şeyh Şemun, Hikmet Ali’ye aslında Zeli’nin akıl 
dengesinin yerinde olmadığını, okuduğu dini bir kitaptan sonra Yezid’in kızı olduğuna inandığını ve kendisi ile evli olduğunu söyler. Şeyh Şemun, Zeli'ye olan sevgisinden her şeye katlanmış, şatolar kiralamış, Kürtçeyi öğrenmiş, onun her isteğini yerine getirmek için nereye isterse peşinden gitmiştir. Hikmet Ali, önce anlatılanlara inanmaz ancak Zeli'nin sessiz kalması ile gerçekleri kabullenir. Zeliha'ya sevgisini açıkladıktan sonra yurt projesinin o günün şartlarında gerçekleşmesinin mümkün olmadığını anlatır. Hikmet Ali, Zeli'yi tek başına Hindistan, Çin ve Japonya ülkelerini gezmesi, orada güzel zaman geçirmesi, projesini başka zamana bırakması için ikna eder. Zeli, Beyrut'tan bir vapur ile ayrılırken Şeyh ve Hikmet Ali ardından bakakalırlar. Her ikisi de sevdiği kadını kaybetmenin acısını yaşar. Hikmet Ali, Sincar Dağı'nda yaşadığı gönül müsademesinden sakat olarak döndüğünü ve hep sakat kalacağını söyler. Hikmet Ali ve Şeyh Şemun yan yana omuzları çökmüş bir şekilde limandan ayrılırlar.

Zeli için yerleşik bir hayata geçmek ve bir aşka bağlanmak yazar tarafından imkânsız hale getirilmiştir. Tarihsel süreçte etnik kökeni nedeniyle birçok trajediyi yaşamış olan Zeli’nin sevdiği adama kavuşması mümkün değildir. Soydaşlarını dağınıklık ve sürgünden kurtarmayı planlarken kendisi için yeni bir sürgün hazırlayarak sevdiğinden uzak yaşamayı bir yazgı haline getirmiştir. Aynı durum Hikmet Ali için de geçerlidir. Kadın kahraman sürgünden sürgüne giderken sevdiğini de bir anlamda bir yere bağlanamama kaderiyle baş başa bırakmış olur. Yezidin Kızı'nı Uzak Doğu ülkelerine doğru yola çıkaran yazar ileride yazacağı Nilgün serisinin alt yapısını oluşturmuş olur.

\section{2. Çetenin yabancı üyesi: Nina}

Çete romanı, Halep'te yazılır; ancak 1939'da yazarın sürgün dönüşüyle İstanbul'da yayımlanır. Bu eser "Buluşmadan önce, Buluşuyorlar, Buluşmadan Sonra" şeklinde ayrılan üç bölümden oluşur. Rus Grandüşesi olan Nina, kocası Fransız yüzbaşısı Ernest’i bulmak için Suriye ve Lübnan, Fransız Yüce Komiserliği" binasına gider. Buradaki yetkililer, kocasının bulunduğu bölgeye gitmenin tehlikeli olacağını, bu nedenle geri dönmesi ya da Suriye'ye gitmesi için tavsiyede bulunurlar. Bunun üzerine Nina, yardımcısı Tatar Bekirof'tan Beyrut'tan Adana’ya gitmenin yollarını öğrenmesini ister. Nina ve Bekirof'un neden Adana'ya geçmek istediklerini öğrenmek için komiserlik peşlerine bazı ajanlar takarlar. Nina ve Bekirof bu ajanları atlatmayı başararak Beyrut'tan Adana'ya gidecek vapura binmeyi başarırlar. Diğer taraftan Adana Sultanisi Fransızca hocası Nezih Bey, akşam geç bir vakitte evine gidince kapıda çarşaflı biriyle karşılaşır. Bir erkekle karşı karşıya olduğunu anlayan Nezih Bey, kapıdaki kişiyi içeri alır. Yoksul adındaki bu adam, Nezih’in yüzbaşısı Demir Bey'den bir mektup getirerek onu çeteliğe davet eder. Nezih, hemen kabul ederek yüzbaşı ile görüşmek üzere evden ayrılır. Nezih, adını Kıran Bey olarak değiştirip Amuk Ovası, Amanoslar, Kızıldağ, Kuseyir dağlarında varlık gösteren bir çete reisi olur. Kıran Bey ve çetesi kısa zamanda ünlenir ve büyük başarılar elde ederler. Öksüz ve Yoksul deniz kenarına indikleri bir gün silah sesleri duyarlar. Kısa bir çatışmadan sonra deniz kenarına birinin düştüğünü fark ederler. Silah seslerinin geldiği yere gittiklerinde deniz kenarına düşenin erkek kıyafeti giymiş bir kadın olduğunu görürler. Kıran Bey’in uygun bir karar vereceğini düşünerek kadını Kıran Bey'in yanına götürürler. Kadın Beyrut'tan Adana'ya gitmek için vapura binen Nina'dır. Ajanlar Bekirof'u öldürmüss, Nina da yaralı halde deniz kenarına düşmüştür. Öksüz ve Yoksul, Demir Bey'den yardım istemek için dağdan ayrıldıkları zaman Nina ve Kıran baş başa kalırlar. Birbirlerine hayat hikâyelerini anlatırlar. Nina; Rus prensesi olduğunu, Finikelerden kaçarken İstanbul'a geldiğini, kocası Fransız Yüzbaşı Ernest ile kendisini koruyup sahip çıktı̆̆ için evlendiğini anlatır.

Kıran ve çetesi, bir süre sonra Nina’yı gideceği yerin yakınına bırakarak yollarına devam ederler. Nina, Fransızların Kıran ve arkadaşlarını pusuya düşürerek saldıracaklarını öğrendiği için geri döner. Âşık olduğu adamı kurtarmak için onları takip eder. Çete üyelerinden birinin yaralanması üzerine Nina onun 
yerine geçerek Fransızlara çatışır. Öksüz, kendilerine diğer Türk kuvvetlerinden yardım geldiğini sanırken Nina'nın inlemeleri üzerine onları kurtaran kişinin Nina olduğu ortaya çıkar. Ankara Antlaşması, imzalanınca Kıran Bey Çetesi dağılır. Hatay'ın anavatana katılmasından sonra on sekiz yıl geçer. Ege kıyılarında gezen bir gazeteci, oradaki halk hakkında bilgi almak için dağın başında, denize bakan, bahçesinde palmiyeler olan bir eve gider. Bu evde Kıran, Nina ve onların kızı Gülcihan yaşamaktadır.

\subsection{Türk prensesi, Mapa melikesi: Nilgün}

Roman, ilk baskıları üç ayrı cilt şeklinde yapıldığı halde (Türk Prensesi Nilgün 1950, Mapa Melikesi Nilgün 1950 ve Nilgün’̈̈n Sonu 1952) daha sonra 1960 yllında Nilgün adıyla tek cilt olarak yayımlanır. Roman kahramanın Ömer, ülkeler arası yolculuk yapan biridir. İtalyan askerlerinin yoğunlukta olduğu Conte Vorte adlı yolcu vapurunda seyahat ederken kendisine bir mektup gelir. Mektup bir Osmanlı prensesi olduğunu iddia eden Nilgün'den gelmektedir. Ömer mektuptaki kadının para istemek amaciyla böyle bir yalana başvurduğunu düşünmesine rağmen onunla görüşmek için yanına gider. Vapurda herkes bir prenses ve teyzesinin olduğundan bahsetmektedir. Ömer; önceki ziyaretinde darmadağınık halde gördüğü Nilgün ve teyzesinin mükemmel giyimleri, toplum kurallarına uygun davranışları karşısında şaşkına döner. Çünkü mektubu aldıktan sonra görüşmeye gittiğinde Nilgün’ün davranışları ona bir prenses olamayacağı izlenimi vermiştir. Vapurda bulunan önemli kişiler Nilgün'den gözlerini alamazlar. Bombay'da inen Ömer; Dilbeste ve Nilgün'ün kalacakları pahalı bir oteli duyunca şaşırır. Paraları olmamasına rağmen o otelde kalmalarına anlam veremez. Nilgün; Ömer'e çeşitli oyunlar oynar. Ömer her defasında onunla bir daha görüşmemeye karar verse de bir şekilde kendisini Nilgün'ün oyunları içerisinde bulur.

Ömer, Nilgün'e âşık olur ve ona rahat bir hayat sağlamak için arkadaşı Tayfur'un yardımıyla bir deniz ticaretinde iş bulur. Bu iş için bir süre denizlerde olması gerekir. Yolculuğa çıkmadan önce Nilgün'le nişanlanır. Ömer vapurla yola çıtıı̆ı̆ günlerde parasını kumarda kaybeder. Aşırı alkol alması nedeniyle sıtma nöbetleri geçirir. Hemşire Atiye'nin yardımıyla iyileşir. Nilgün'ü aramaya başlar, onun Kalküta'da olduğu öğrenir. Ömer, ortadan kaybolduktan sonra iki yıl geçmiş, bu sürede Nilgün'ü arayıp sormadığı için Nilgün Mapa Kralı Ahmet ile evlenerek Mapa Kraliçesi olmuştur. Ömer Nilgün’ü kocasının yanında görünce çok acı çeker. Tayfur ve Dilbeste'nin planıyla Ömer, Nilgün'ü Mapa'ya götürecek olan vapura biner. Nilgün, Mapa'da Ömer için bir köşk hazırlatır. Ömer sekiz ay kadar Nilgün’ün yanında kalır. İkinci Dünya Savaşı'nın Mapa'ya sıçrayacak olması ihtimaliyle Prens Ahmet karısını ve doğacak olan çocuğunun hayatını kurtarmak için Nilgün'ü, Ömer ve yeğeni Gaffar'la beraber ülkeden kaçırır. Cava'da Nilgün doğum yapar. Ömer, bu savaş ortamını solumak istediğini yazarak Nilgün'ü bırakıp gider ve bir süre sonra Japonlara esir düşer. Ömer bir yolunu bulup Japonların elinden kurtulur. Nilgün'ün Lübnan'da olduğunu öğrenince oraya gider. Ancak bulduğu kişi aradığı Nilgün değildir. Bu gördüğü kadın gerçek Osmanlı Sultanı Nilgün'dür. Çeşitli maceralar yaşadıktan sonra Kanarya Adaları'nda Nilgün’ü bulur. Nilgün'ün kocasının savaşta öldüğünü, oğlunun ise onunla olduğunu öğrenir. Kısa bir süre sonra Nilgün ve Ömer evlenerek yaşadıkları özleme bir son verirler.

\section{Refik Halit’in sürgün kadınlarının ortak özellikleri}

Refik Halit, yaşadığı sorunları kadın kahramanlarının hayatına yansıtarak kendi sürgününe zemin hazırlayan siyasi, sosyal ve ekonomik olayları ve yeni yaşam biçimlerini sorgular. Böylece yaşamından örneklerle var olanı eleştirel bir yaklaşım ile ortaya koyarken kadın kahramanlarının trajedisiyle sürgünün ağırlı̆̆ını aktarır. Bu nedenle eserlerindeki kadınlar, hemen hemen birbirinin aynısıdır. 
Yazarın kahramanları onun ruh eşleri gibidir. Onları kendi duygularının tercümanı olarak kurgular. Çoğunlukla yaşanmış olayları kaleme alan yazarın kahramanları kendilerini herhangi bir yere ait hissetmezler. Bu nedenle sık sık ülke değiştirirler. Genellikle çeşitli nedenlerle ülkelerinden ayrılan kahramanlar yine bir tesadüf eseri olarak birbirleriyle tanışıp bir araya gelirler. Yabancı bir ortamda konuşulan ortak dil, bu tanışmayı başlatan unsur olarak ele alınır. Bazen Arap coğrafyasında konuşulan Türkçe bazen de Anadolu'da konuşulan yerel diller kahramanın dikkatini cezbeder, böylece tanışma süreci kolaylaşmış olur. Yezidin Kızı romanında Arjantinli olan Zeli’nin Kürtçe konuşması, İspanyolca ve Fransızca bilmesi onun çevresi tarafından tanınmasını ve ilgi görmesini kolaylaştırır.

"İspanyolca gazete okuyan kadın, geri geri huzurundan çekilen sakallıya: "Dü saat şunde veri cemmi!" demişti." (YK, 9)

Lübnan Komiserliğinde kocasıyla ilgili bilgi alırken Fransızca konuşan Rus Prensesi Nina, Kıran ve çetesi tarafından bulunduktan kısa bir süre sonra onlarla Türkçe konuşur. Bu durum onunla ilgili şüphelerin artmasına neden olur. Nilgün ise Zeli ve Nina'yı geride bırakacak kadar dillere hâkimdir. İtalyan, Japon ve çeşitli ülkelerin askerleri ile kolaylıkla iletişime geçen Nilgün, bildiği diller sayesinde birçok kişi ile arkadaşlık kurar, işlerini kolayca hal eder.

“Kaleye döndükleri zaman Kıran'ın yanına paldır küldür giren çeteci haykırdı:

Avrat Türkçe konuştu! Türkçe konuştu!

Kıran raporunu yarıda bıraktı; biraz sararmıştı; kaşları çatılarak kendi kendisine söylendi:

Bu ne biçim- iş? Bu ne şaşılacak kadın!” (Ç, 78)

Her üç kahraman da belli bir mekânda duramazlar, daima yolculuktadırlar. Bir ülkeden başka bir ülkeye hareket eden kadın kahramanlar için İstanbul'dan ayrılıp Ortadoğu'ya doğru yol almak ya mecburiyet halini almıştır ya da çeşitli serüvenlerin peşine düşmeleri sonucunda kendilerini bu yolculukta bulmuşlardır. Refik Halit aslında yolculuğa çıkardığı bu kadın kahramanlar şahsında kendisinin İstanbul'dan ayrılışında hissettiklerini daha duygusal bir varlık olan kadın psikolojisiyle dile getirirken duyguların yoğun bir şekilde okuyucuya geçmesini ister. Kahramanlar da yazarın kendisi gibi memleket özlemi içindedirler. Memleket özlemini "yerim; oteller pansiyonlar olacak; bütün alışık muhit ve eşyadan mahrum bir ömür sürecek, başkalarının artıkları üstünde yatıp kalkacak, öz ve asil kokudan, bucak kokusundan uzakta yaşayacaktım...(Karay, 2009: 341) " şeklinde dile getiren yalnız yazar değildir. Kadın kahramanlar da daima "öz ve asil kokuyu" ararlar. Onların da "bedeni sürgünde, ruhu tümüyle memlekette”dir (Tosun, 2010: 65). Zeli, Marsilya'dan Ortadoğu’ya oradan da Sincar’a doğru yola çıkar. Gittiği her yerde başka bir role bürünerek kendisini inandırdığı "Yezidin kızı" görevini tamamlamaya çalışır. Soydaşlarının yaşadığı sürgünden sıklıkla bahseden Zeli için her yer sürgün yeridir. Aynı şekilde Nina, saraya mensup bir prensesken ülkesinin geleceği tehlikeye girince çeşitli tehlikeli işlerde askerlere öncülük ederek savaşır. Bu durum onun kişilik olarak gelişmesine yardım etse de beraberinde birçok tehlikeyi getirir. Nina ülkesinde kalamaz ve düşmanlarından kaçarak İstanbul'a gelir. Böylece Nina da ülkesinden ayrılmak mecburiyetinde kalır. Nilgün ise Osmanlı hanedanının sürgün bir bireyi olarak yoldadır. Anlattıkları ile bazen sürgün olmanın zorluğunu dile getirirken bazen de bunların birer oyundan ibaret olduğunu ortaya koyar.

Zeli Yezidilerin, Nina Rusların, Nilgün Osmanlının kararlı, cesur ve planlı prensesleridir. Planlarını devreye koymak için tehlikeye atılmaktan geri kalmazlar. Nina takip edildiğini bildiği halde tehlikeli bir yolculuğu göze alır. Kocasını kurtarmak için erkek kılığına girerek Beyrut’tan Adana'ya giden vapura biner. Nil; Beyrut, Mapa, Japonya vb. birçok ülkeye gidip kurmak istediği yaşam için her şeyi göze alır. Bu durum uzun yolculukları, tanışıklıkları ve aşkı beraberinde getirir. Devam eden serüvenlerin ve aşkın 
merkeze alınması, kadın kahramanların bu aşk etrafında şekillenmesini hızlandırır. Kadınların güzellikleri, güçlülükleri ve azimleri aşk duygusuyla iç içe verilir. Karay’ı kadın kahramanları girdikleri her ortamda güzellikleri ile daima bakışları üzerlerine çekmeyi başarırlar. Kadınların boyu, vücut yapıları, saçları, ten ve göz renkleri ilgi çekecek şekildedir. Böylece yazara, kadın tasvir ve tahlillerinde kıyafet, makyaj, takılar ve özellikle kokulara dair söyleyecek çok söz düşer. Özellikle renklerin ve kokuların betimlemeye kattığı canlılıktan faydalanarak yaptığı tasvirler Karay'ın kadınlar hakkında bazen sayfalarca değerlendirmelerde bulunmasını kolaylaştırır. Bu durum ise okuyucuya sokağa çıması durumunda kahramanı bir yerlerde görse tanıyabileceği hissi verir. Zeli tanıtılırken doğayla özdeşleşen pek çok ayrıntıya yer verilir. Bu betimlemeler, onun girdiği ortamlarda yaratacağı etkiyi önceden sezdirmeye yöneliktir.

\begin{abstract}
"Batı güneşi vurmuş harman yığınındaki buğday taneleri gibi altınımsı, sıcak bir esmerliği var. Bu çehreyi henüz şekerci elinde çekilen ağda renginde, gölgeli ışıklar yapan, kesilmemiş bir saç çerçeveliyor. Daha sonra taze güneş altında gözlerini gördüm: Mor susam kadifeliğinde birer geniş halka kehribar renginde daha küçük halkalara geçmiş, nemli ve serin parıldıyorlar.
\end{abstract}

Nil ise her ortama uygun giysileri, makyajı ve hareketleri ile esrarengiz bir kimliğe bürünmüştür. Fiziki güzelliğinin yanı sıra kültürel bilgisi, bulunduğu ortama kattığı neşesiyle her an sürpriz yapacak bir yapısı vardır. Nilgün, Osmanlı’nın izlerini taşımaktan çok yeni kurulmuş Cumhuriyet'e özgü bir dünyanın kadınıdır. Farklı zamanlarda büründüğü farklı kültürlerin giysileri içinde yeni dünyanın bir sembolü gibidir. Eser boyunca Nil’in zekiliği, maceraperestliğini vurgulamak için Mapa, Samers Köşkü, Seylan adası gibi egzotik yerlerdeki faaliyetlerine yer verilir. Bu durum aslında maceraperestliğinin yanında içinde olduğu şartların zorluğundan da kaynaklanır. Çelik (2015: 391) Nilgün'ün sürgün koşulları nedeniyle zaman ve maddi konuların akışına kendini bıraktığını belirtir. Sık sık başvurduğu hileler, yalanlar ve oyunlar aslında ne istediğini bilmeyen Nilgün'ü egzotik ortamlar içinde daha çekici ve esrarengiz kllar. Rus Prensesi Nina ise diğer kahramanların aksine kısa boylu olarak tasvir edilir. Ancak onun da güzelliği ve şıklığıyla askerler üzerinde yarattığı etki, Zeli'nin vapurdakiler üzerinde yarattığı etkiye benzer. Nina "ufak tefek ama güçlü, ince kaşlı, toparlak çeneli, iri ağızlı, dolgun yanaklı bir kadın”dır. "narçiçeği dudaklı” Nina, çok çekik gözleriyle Sibiryalı, Kalmuk, ya da Özbek kadınlarına özgü özelliklerle ön plana çıkarılır.

Romanlarda erkek kahramanlar kadınlara göre daha yaşlı ve hayattan bezmiş durumdadırlar. Zeli 2025 yaşlarında atılgan bir kadınken Hikmet Ali 45 yaşında her şeyden el çekip dinlenmek için köyüne giden bir erkektir. Aynı şekilde Nilgün; genç bir kız, Ömer 45 yaşlarında herhangi bir işe veya yere bağlanamayan biridir. Kıran Bey ise Nina'dan büyük olmasına rağmen diğer iki erkek kahramana göre daha tutarlıdır. Bu durum kadınların özelliklerinin daha belirginleştirilmesi amacıyla tercih edilmiştir. Orta yaşlı ya da yaşlı erkeklerin karşısına çıkan genç, güçlü, akıllı ve güzel kadınlar büyük aşk maceralarının başlamasında etkili olurlar. "Her an bir sürpriz beklenen, erkeğin aklından geçenleri hareketleri, bakışları ve konuşmasından sezecek kadar zeki, velhasıl varlığıyla huzur telkin eden, ayrılığına tahammül edilemeyen” (Aktaş, 1986) bu kadınlar genellikle casusluk yapmalarıyla ünlüdürler. Nina, Çarlık Rusya'sı döneminde saray adına casusluk görevini üstlenir. 1917 Rus İhtilalinin olduğu dönem çok maceralı bir hayata atılır. Zeli, Hikmet Ali’nin aklında ve rüyalarında bir casus olarak yer alır.

"Kendi kendime diyorum ki: Bir casusla karşılaştım. Bu kadın şüphesiz bir sulh devri Mata-Hari"esi, bir froylayn doktor, bir Miss Lawrence"dir. Avrupa ve Asya"ya ilk defa gelmiyor; şüphesiz harabeleri gezmek isteyişi kaba bir yalandır. Bizi, bizim kadar biliyor ve muhakkak yolculuğunu bir vazife olarak kim bilir neler çevirmek için yapıyor. 
Her üç romanda da kadınlar böylesine güçlü gösterilmelerinin yanı sıra aslında onların maruz kaldığı şartların ağırlığına vurgu yapılır. Kadınların her üçü de savaş ve siyasi ilişkiler mağdurudur. Bir erkeğin üstlenmesi gereken vazifeleri üstlenmişlerdir. Savaş ve sürgün durumu her üçünü de istemedikleri evliliklere sürüklemiştir. Zeli kendisini koruyan, her istediğini yerine getiren Şeyh Şemun ile evli olmasını kabullenmiş değildir. Onu kölesi olarak tanıtması kendisine eş olarak görmek istemeyişinin bir göstergesidir. Gerçeklerin ortaya çıkışı ile sessiz kalmayı tercih etmesi bir anlamda akıl hastası olmaktan çok kendisini koruyan bu adamı dış çevreye karşı bir kalkan olarak kullanmasından kaynaklı bilinçli bir tavrın tercih edildiğini gösterir. Akıl hastası rolü ise Şeyh Şemun’a karşı kendisini korumaya yönelik geliştirdiği bir savunmadır. Zeli, Şeyh ile âşı olduğu için değil kendisini koruma amacıyla evli kalmıştır. Nina'nın durumu da Zeli'den farklı değildir. Nina bir anda Rus sarayında içinde bulunduğu ihtişamı kaybetmiş, kendisini bir erkek gibi savaş alanında bulmuştur. Fransız Yüzbaşı Ernest ile olan evliliği, yine sevgi kaynaklı bir evlilik değil, güvenliğini sağlamaya yönelik bir ihtiyacın sonucudur. Nil'in yaşadıkları ise travma geçirmiş bireyin mağduriyetini yansıtır. İhtişamlı bir devletin sürgün bireyi olarak üçüncü sınıf bir kamarada yolculuk yapmak zorunda olan Nilgün, kendisine eski lüks yaşamını sunacak birini bulmak için her firsatı değerlendirmeye çalışır. Melik Ahmet ile para ve güç ve güvende olma amacını elde ettiği için evlenir. Ömer'e âşık olmasına rağmen sefalet içinde geçireceği bir yaşamı göze alamaz. Kısacası sürgün, bu kadınların kendilerini güvende ve lüks içinde hissedecekleri aşk, sevgiden yoksun evlilikler yapmaya mecbur bırakmıştır.

Kadınların sonunu yazarken aslında bütün iyi özelliklerin aynı kişide bulunmasının imkânsızlı̆̆ını ortaya koymak istercesine yazar, onların ya akıl hastası olduğunu ya da belli dönemlerde tımarhanede kaldıklarını ortaya çıkarır. Yezidin Kızı'nda Zeli'nin bir akıl hastası olduğunu Şeyh Şemun aktarır. Nilgün ise uydurduğu hikâyelerle bir psikopata özgü tavırlar sergileyip Hikmet Ali’yi çıldırtma seviyesine getirir. Ömer yaptırdığı araştırma neticesinde Lübnan'da akıl hastanesinde bir süre tedavi gören Osmanlı hanedanına mensup Nil isminde bir kadın olduğunu öğrenir. Bu kadının Nilgün olup olmadığı kesinleştirilmese de özellikleri dikkate alındığında Nilgün olma ihtimali güçlenir.

\section{Sonuç}

Sürgün toplum ve birey hayatında önemli sonuçları olan bir durumdur. Sürgüne mahkûm olan bireyin göçten farklı olarak zorunlu bir şekilde alışık olduğu düzeni bırakması nedeniyle psikolojik etkilere de sahiptir. Bu nedenle sosyoloji, psikoloji ve edebiyatın ilgi alanına giren bu durumun yaşama kattıkları ve yaşamdan götürdükleri üzerinde durulmaya değerdir. Edebiyatımızda toplumun sosyal ve psikolojik çizgilerini eserlerine yansıtan Refik Halit’in Yezidin Kızı, Çete ve Nilgün romanlarında sürgün koşulların alt üst ettiği kadın yaşamlarına değinilmektedir. Kadınların mensubu oldukları etnik, sosyal veya siyasi çevre onların sürgün yaşamının başlamasında önemli rol oynamaktadır. Savaş yıllarının ortaya çıkardığı karışıklıklar, erkeklerden çok kadınları mağdur etmiştir. Saraylarda büyüyen kadınların birden bire birkaç eşyaya sahip bir bireye dönüşmeleri, onların psikolojik olarak derinden yaralanmalarına neden olmuştur. Güvenecekleri kimseleri olmayan bu kadınların yurtlarından kopartılmış olmaları onları bir arayış ve güvenlik endişesi içerisine sürüklemiştir. Bu süreçte çevresindekilere güçlü ve zengin kadın imajı çizmeye çalışan bu bireylerin aslında ruhsal olarak büyük bir çöküntü içinde oldukları, güvenebilecekleri, güçlü erkeklere ihtiyaç duydukları gözlenir. Evlilikleri, hareketleri ve isteklerinden tutarlık görünmeyen bu kadınlar sürgün psikolojisinin ortaya çıkardığı bireylerdir. Yazar kendi yaşamından yola çıkarak çizdiği bu kadın portreleri üzerinden toplumsal ve psikolojik etkileriyle sürgünün birey yaşamına olumlu ve olumsuz etkilerini edebiyatımıza taşımıştır. 


\section{Kaynakça}

Acehan, A. (2007). “Tanzimat Fermanı'ndan Bugüne Edebî Sürgün”. TÜBAR-XXII, s. 9-24.

Andaç, F. (1996). “Sürgün Sözlerin Anlamı”. Sürgün Edebiyat, Edebiyat Sürgünleri. İstanbul: Bağlam.

Aktaş, Ş. (1986). Refik Halid Karay. Ankara: Kültür ve Turizm Bakanlığı.

Baydar, O. (1996). "Yazmaya Sürgünde Başlamak”. Sürgün Edebiyat, Edebiyat Sürgünleri İstanbul: Bağlam.

Campbell, J. (2000). Kahramanın Sonsuz Yolculuğu. İstanbul: Kabalcı.

Çelik, Y (2015).“Sürgünün Meydana Getirdikleri: Yezidin kızı, Sürgün ve Nilgün Romanlarında Göç ve Sürgün Belirtileri”. Türk Göç Konferansı 2015. London. 388-392.

Göze, F. E. (2013). “ Kahramanın Yolculuğu: Beyazperdede Çocukların Kahraman Olma Macerası”. Turkish Studies - International Periodical For The Languages, Literature and History of Turkish or Turkic Volume 8/8 Summer s. 1793-1804.

Gürsel, N (1996). “Sürgün ve Yazın”. Sürgün Edebiyat, Edebiyat Sürgünleri İstanbul: Bağlam.

Karay, R. H. (2009) Minelbab İlelmihrab. İstanbul: İnkılap.

Karay, R. H. (2015). Yezidin Kızı. İstanbul: İnkılap.

Karay, R. H. (2009). Çete. İstanbul: İnkılap.

Karay, R. H. (2009). Nilgün. İstanbul: İnkılap.

Tosun, N. (2010). Sürgündeki Öykücü: Refik Halit Karay. Kitap-llk Dergisi, S.144, s. 63-67. 